Performing Centaurs and the Debasement of Masculinity

\title{
Marta Segarra
}

Centre National de la Recherche Scientifique / Universitat de Barcelona

Email: marta.segarra@cnrs.fr

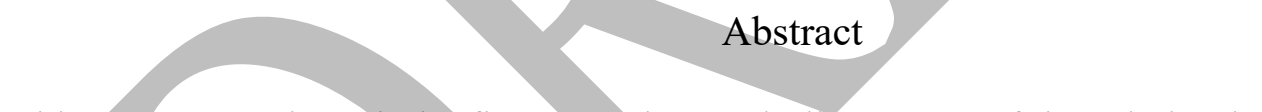

This paper examines, in its first part, the symbolic aspects of the relation between horses and men, and the mythical figure of the centaur, most often assimilated to virility and male sexual drive, but also to women and their sexuality. In its second and central part, it focuses on Bartabas and Ko Murobushi's performance, The Centaur and the Animal (2012), while raising ethical issues relating to performing animals. The essay analyzes how this play deconstructs the opposition between masculinity and femininity, as well as between animal and human, among other oppositional pairs such as reason vs. instinct, activity vs. passivity, verticality vs. horizontality or "inclination," immunity vs. vulnerability, life vs. death, animate vs. inanimate, among others. It posits that Bartabas's performance opens the 
possibility of a posthuman and postanimal perspective on the relation between human and nonhuman animals.

Keywords: performing animals, centaur, butoh, posthumanity, Bartabas

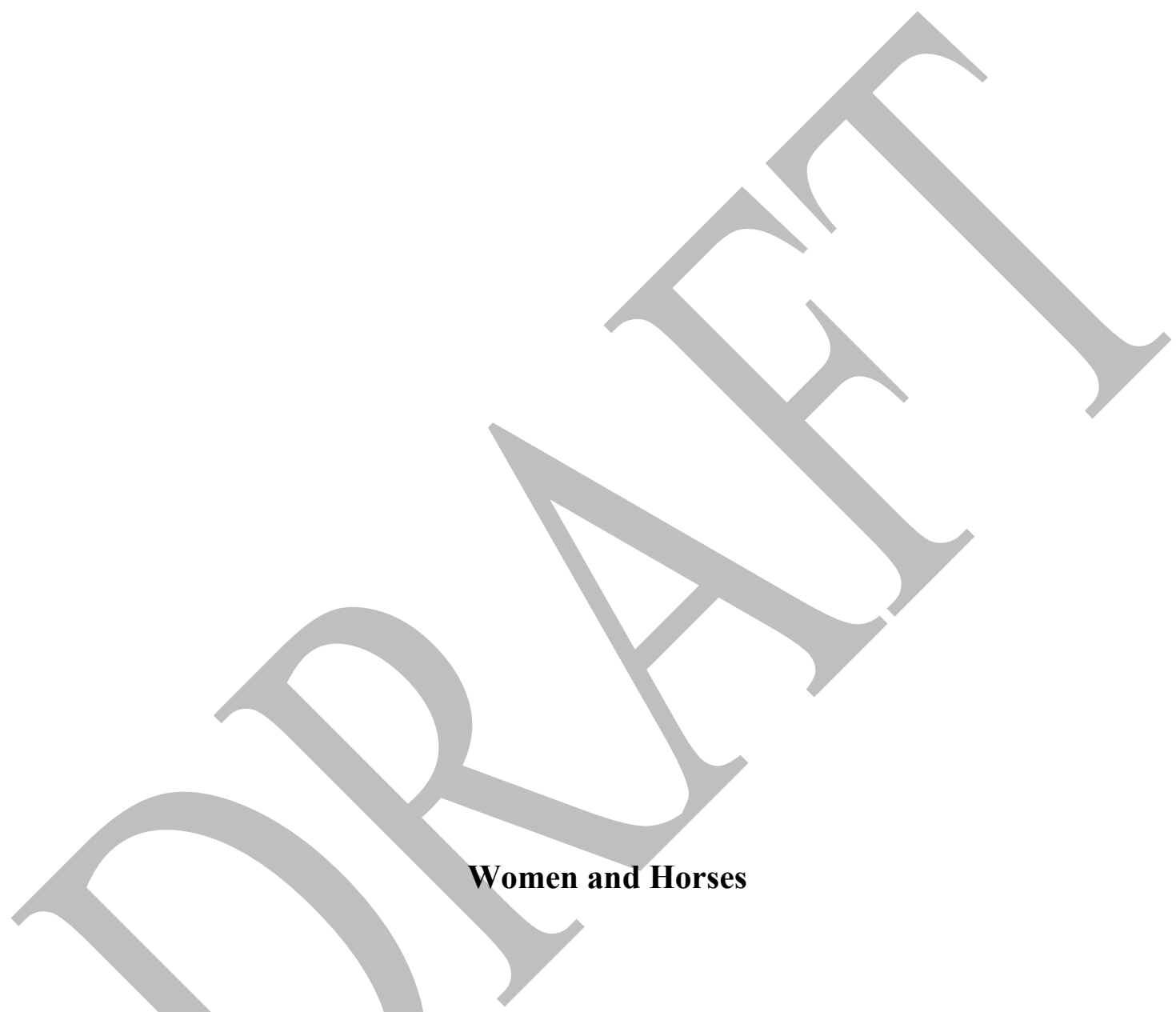

If women have often been identified with nonhuman animals in western tradition, due to the opposition between Nature and Culture and the assimilation of women to Nature, horses have generally been considered as the epitome of masculinity-although they have also been seen as a symbol of dangerous, active female sexuality. Horse-racing, training, hunting and riding were associated with men and linked to virile attributes, although this identification has been problematized, as we shall see. Since their origins, western literature and visual arts have related horses to war and chivalry, which were exclusively male 
activities: the Trojan horse in the Odyssey, singularized horses in epic poems and chivalric romances, or the Conquistadores' horses in Spanish Chronicles of the Indies are some examples (see Ortiz Robles, 2016, p. 37). Kings were also traditionally portrayed on top of a horse, as a symbol of sovereignty (see Derrida, 2009). Even in the nineteenth century, when upper-class women in some European countries, especially in Great Britain, used to practice horse-riding, this sport still conveyed masculine values - that is why women riders were called "amazons" in languages such as French or Spanish, a term that assimilated them to ancient women warriors. "Dominance over large animals [which includes horses] had been a longstanding boast of macho masculinity," making of the cowboy an "archetypal masculine figure" (Tait, 2012, p. 155), as can be seen in nineteenth-century circuses (Buffalo Bill's show, Buffalo Bill's Wild West, toured along the United States and Europe between 1883 and 1906) and rodeos in the western United States and northern Mexico, and later, in twentiethcentury cinema and genre literature such as romance novels, where contemporary cowboys are still supposed to incarnate virility.

However, according to Buffon, horses have two main qualities: courage and docility, the first deemed "masculine" and the second "feminine" (Sibona, 2014, p. 61). In nineteenthcentury literature, horses were also depicted as victims of human cruelty: Anna Sewell's bestselling novel Black Beauty (first published in 1877 and later adapted to cinema and TV) and Tolstoy's Kholstomer. The History of a Horse (published in 1886) are prominent cases, since both authors chose to make the horse speak in the first person as the narrative voice; the same applies to the Countess of Ségur's novel, Les Mémoires d'un âne (A Donkey's Memoirs, 1860). ${ }^{1}$ As horses progressively left their role in military endeavors and in human transportation, and became a "companion species," they were more and more associated to

\footnotetext{
${ }^{1}$ See Berger (2011) for a critical reading of Madame de Ségur's novels from the vantage point of animal studies.
} 
women (see Marra, 2014). Feminists such as Donna J. Haraway (2003, 2008) and Kim Marra (2014), or horse trainer Vickie Hearne (1986), have elaborated on this relationship, which has also been included into an "ethics of care" by ecofeminist theorist Josephine Donovan (2016). Donovan notes that Martin Buber, in his seminal essay, I and Thou (1923), explains that, when stroking the neck of a beloved horse during his childhood, "what I experienced in touch with the animal was the Other, the immense otherness of the Other, which, however, did not remain strange ... but rather let me draw near and touch it" (as cited in Donovan, 2016, p. $81)^{2}$

Women have been considered to be more receptive to "the Other" than men, not by a natural inclination — although the "biological" argument of "maternal instinct" has also been claimed-, but due to the cultural construction of "femininity," implying a more acute sensitivity to the needs and emotions of others, an openness that is also imaginarily located in women's bodies. As Judith Butler (2014, p. 104) states, “a lamentably long tradition in philosophy" has regarded "the bodily dimension of the human" as its "animal dimension." Although those who believe in "essential" masculinity also think that it is linked to the male body (Connell, 2005, p. 45), the animalization of the female body has been more frequent than of the male body, due to its link with reproduction. But this is a cultural assignation, since the "homosexual" male body is also conceived as more open and prone to contagion (in the sense of affective or emotional contagion, too) than the male heterosexual body, which is seen as hermetic and impervious. These "naturalized," porous bodies—which I have called "holed bodies" (Segarra, 2014) — are considered more vulnerable than the male body. "Vulnerable" etymologically refers to a "wound" (vulnus in Latin), which sends us back to horses, since, according to paleoanthropologist André Leroi-Gourhan, the horse was often associated to the wound in Prehistory (Sibona, 2014, p. 61). Women's sex is yet seen as a

\footnotetext{
${ }^{2}$ The original quote may be found in Buber (1965, p. 23).
} 
bleeding wound; since ancient times, a bleeding body relates to menstruation and to animal sacrifice and hunting, both being "masculine" activities (Donovan, 2016, pp. 170-173).

\section{Dancing Centaurs}

All these associations are present in some way or another in the performance that will be analyzed in this paper. Since this performance is entitled Le Centaure et l'animal (The Centaur and the Animal), we will briefly examine first the meaning and imaginary associations of the "centaur." Centaurs, present in many ancient traditions around the world, are mythical creatures, half-man, half-horse. ${ }^{3}$ It is believed that they were imagined by people of non-riding cultures when meeting face-to-face men riding horses. Conquistador Bernal Díaz del Castillo describes for instance in his memoirs, A True History of the Conquest of New Spain (written in 1576), how Aztecs, who had never seen horses, thought that horse and rider were one and the same creature. The ancient Greek linked centaurs, similar to satyrs, to animal appetites and to excessive, violent virility; triggered by wine intoxication, centaurs had an annoying tendency to try to abduct and rape young women and boys (Graves, 1955, entry 102), although they were always defeated by "civilized" heroes. However, Georges Dumézil (1929) also linked centaurs to women, fertility, and hospitality, as well as with civilization, pedagogy, and music. The double nature of centaurs made them interesting for Machiavelli, who connected them to his ideal Prince; as Derrida (2009, p. 128) argues, the sovereign must also be "double," animal and man.

The Centaur and the Animal is a dance performance created by Bartabas in 2010, also released as a DVD in 2012. Bartabas is an artist based in Aubervilliers, near Paris, who always works with horses in his shows. His company is called Le Théâtre équestre Zingaro

\footnotetext{
${ }^{3}$ Although female centaurs or "centauresses" are also attested, they are much rarer.
} 
(The Tzigane Equestrian Theater) and their performances - which include a powerful version of Macbeth — are grounded on the interaction between "animal actors" and "human actors," in Bartabas's words. His work is also characterized by the "hybridization" he fosters between different cultural traditions, for instance the rites of Tibetan monks, avant-garde European music, the Mexican cult of the dead, or Japanese theatrical tradition, among others. The Centaur and the Animal features a Japanese butoh dancer, Ko Murobushi, and uses the Comte de Lautréamont's Chants de Maldoror as script. However, the most relevant hybridization in this performance is the one between horse and man: the human actor and the horse actor form a single creature that might be identified as a "centaur" (but, in reference to the title, one can wonder who would then be the "animal"...). In fact, The Centaur and the Animal does not oppose "animal" to "man," animate to inanimate, life to death, or, more interestingly for us, "masculine" to "feminine," but makes them dance in an entangled “choreography" - in allusion not only to Donna Haraway's “ontological choreography" (2003) of dogs and humans, but also and above all, to Derrida's dialogue with Christie V. McDonald (1982), where the philosopher vindicates a multiplicity of gender combinations, beyond the binary opposition man-woman or masculine-feminine.

Traditional and, more extensively, contemporary dance often foster new forms of experiencing the body, and thus, of performing different embodied subjectivities, which may likely escape cultural and gendered codes. Hélène Marquié $(2009$, p. 127) describes how modern dance, especially from Martha Graham on, welcomes animality as a "line of flight" (Deleuze \& Guattari, 2004) of body "domestication" or "discipline," in Foucauldian terms. This escape also allows us to challenge gendered interpretations of movement (some movements being deemed "feminine" and other "masculine") as well as canonical beauty criteria that “normalize” bodies (Marquié, 2014, pp. 64-65; Marquié, 2009, p. 131). 
Butoh is a dance form that is especially prone to the invention of new "corporeities" (Pagès, 2015, p. 70). Butoh was born in Japan at the end of the 1950s, influenced by French auteurs maudits such as Lautréamont, Artaud or Genet. One of its initiators, Tatsumi Hijikata, wanted to expose on stage the presence of outcasts, of the "nonpeople" of the Japanese community of the time: that is the homeless, the prostitutes, the drunkards, the poor (Sanders, 1988, p. 148) and also marginalized gay men. ${ }^{4}$ Butoh deals, thus, with the limits of community - trying to expand them—, to vulnerability (it has also been frequently linked by western critics to the trauma created by the nuclear bombs' explosions that killed or maimed thousands of people and animals in Hiroshima and Nagasaki), and to the hybrid, since one of butoh's main themes is metamorphosis, based on an acute feeling of non-permanence, reflected in the famous expression "mono no aware" (Sanders, 1988, p. 158). In The Centaur and the Animal, Bartabas and the butoh dancer Ko Murobushi-himself a disciple of Hijikata — share the stage with four horse actors (one at a time). The "emaciated bodies" (Nanako, 2000, pp. 24-25) of the human dancers appear in sharp contrast with the powerful physical presence of these extraordinary animal dancers, but Bartabas — who, more than riding the horses, seems to merge with their bodies-creates a hybrid on the stage that seems to be real.

\section{Ethical Issues about "Horse Actors"}

Before analyzing in detail some of the most relevant scenes of The Centaur and the Animal, some ethical issues of interspecies performances should be brought up. ${ }^{5}$ As said,

\footnotetext{
${ }^{4}$ As shown by the pictures by Japanese photographer Shomei Tomatsu (which could be seen, for instance, in the exhibition curated by Juan Vicente Aliaga for the Fundación Mapfre, Barcelona, June-September 2018).

${ }^{5}$ For an overview of ethical issues regarding interspecies performances see Chaudhuri (2010).
} 
Bartabas alludes to the horses who are part of his shows as "animal actors." Conversely, Broadway animal trainer William M. Berloni argues that animals can never be treated as "actors" since "they are the ultimate reality, they are in the real moment, not acting" (Berloni, 2017, p. 11). This trainer is adamant about not giving the name "actors" to animals onstage (p. 15), since that would mean "anthropomorphizing" animals, forgetting the differences that distinguish them from $u s$. This argument ignores ethological evidence that many nonhuman animals, mostly mammals but also some birds, and even invertebrate cephalopods, like to play, even in adulthood. Playing implies a capacity of distinguishing reality from fiction, an ability to feign close to what actors do when playing a role. Jacques Lacan acknowledged that some animals were capable of feigning, especially in the context of hunting or of a sexual parade, a quality he called "dancity,"6 since he related it to dance (Lacan, 2006, p. 683). Bartabas claims that some horses actually like acting onstage, which means interacting with him and the other human actors, and with the other horses participating in the show. In his performances, one can rarely notice in "horses actors" bodily signs of fear, tension or discomfort revealed by certain give-it-away signs that cannot be controlled by trainers, such as pinned ears, clamped tail, or unrestlessness. This fact might sustain Bartabas's statements about his companion horses actually enjoying being onstage.

However, training animals for all kind of purposes, among them acting, raises ethical questions, which have been addressed, regarding horses, by Donna J. Haraway $(2008,2016)$, Vicky Hearne (1986), Kim Marra (2014), and Paul Patton (2003), among others. While Haraway and Marra insist on the "avid contact zones" (Haraway, 2008, p. 287) between animals and humans that training fosters, Hearne and Patton stress the "radical translation"

\footnotetext{
${ }^{6}$ Derrida critically comments on Lacan's argumentation in The Beast and the Sovereign (2009, pp. 172-174), since Lacan solely grants this capacity to nonhuman animals in order to distinguish them from human animals: only the latter are able, according to the psychoanalyst, of feigning that they are feigning, that is, of "feigning feint."
} 
(Patton, 2003, pp. 88-89) and the "immersion in [an] alien tongue," adjusting to horses' "kinesthetic language" (Hearne, 1986, p. 107), that training requires. This "immersion" in radical otherness makes humans lose something-albeit the common belief in human exceptionalism-, although all of them insist in the "richness" of these intimate relations. Bartabas has repeatedly claimed that he is attuned to the horses he works with on a daily basis, usually in a long-life relationship, and that the only way to convince them to perform onstage is co-creating the shows with the horses. ${ }^{7}$ The ultimate proof of this statement is, according to its director, his latest show, Ex Anima (2017), which features mostly horses left alone on the stage, moving — seemingly - freely, and doing what horses usually do when not being ridden, such as rolling on their back in order to scratch it, which can be seen by humans as a spectacular action, given the imposing volume of a horse, compared to humans'.

Nevertheless, training always implies a sort of coercion, ${ }^{8}$ especially in its most coded form, dressage, which Bartabas has practiced in older shows, and which also raises questions about race — both of horses and of their riders - class, and gender, being a white upper-class sport, but also the only Olympic contest - along with the other equestrian sports — where women and men, and male and female horses compete on an equal basis. In relation to masculinity, dressage is a very interesting sport since it is "full of queens," quoting Katherine Dashper's paper (2012). That means, according to Dashper's inquiry, that it is a sport in which virile values are less hegemonic than in other sports such as football or rugby; gay sportmen and sportwomen suffer therefore from less homophobia and marginalization than in other

\footnotetext{
${ }^{7}$ See Bartabas series of five 29-minute interviews with for France Culture's program, $\grave{A}$ voix nue, by Martin Quenehen and Véronique Lamendour, entitled Les cinq sens du centaure (15/01/2018-19/01/2018) - the "centaur" being here Bartabas himself.

${ }^{8}$ Regarding ethics involved in horse training, one should distinguish, of course, between very different methods, which go from coercion based on punishment to "horse whispering," popularized by Nicholas Evans's novel, The Horse Whisperer (1995), and Robert Redford's movie of the same title (1998). A deeper discussion on different kinds of training should include, of course, non-western approaches.
} 
competitive sports. Dashper posits that this makes of equestrian sports an exemplary case of “inclusive masculinity” (Anderson, 2009). Considering Bartabas's artistic career, the inclusion of dressage in his shows coincides with other signs of what could be deemed as a devirilization of himself as an actor and as a character onstage (such as wearing long skirts, adopting a more "feminine" body language," making fun of himself, or limelighting women actors).

However, Patton (2003, p. 94) observes that the techniques of dressage appeared at the same period when, according to Michel Foucault, bodies began to be "disciplined," in the seventeenth century. He adds that there is a "fundamental asymmetry" (p. 90) between horse and rider, since the first complies to the latter's orders or hints. It is indeed a relation of power, but intrahuman relationships are not devoid of power tensions either, quite the contrary. Patton adds that hierarchical interactions are not "incompatible with ethical relations and obligations toward other beings" (p. 95). This is what Bartabas has defendedand practiced - all his life, which he has intimately shared with his companion horses, living in a caravan next to the stables, in a similar way as nomad gypsies or circus artists traditionally lived. This has also meant for him a downward mobility, in the sense of renouncing his original social class (he was born in a middle-class French family) for an outcast community.

\section{Demasculinization and Dehumanization}

In the first minutes of The Centaur and the Animal, we are quickly submerged in an intense world of unknown creatures, since the play involves, as said, another author, the Comte de Lautréamont, from whose oeuvre several excerpts are read throughout the performance. The opening fragment is quite appropriate: Maldoror claims to be a "cadaver," 
but a living one, since he is inhabited by several animals, in a profound symbiosis that recalls Haraway's conception of "companion species": he is lice-ridden; a family of toads and a chameleon — itself the paradigm of metamorphosis - have "taken residence" in his armpit. Interestingly, this metamorphosis goes beyond animality, since he compares himself with "a dunghill” where "an enormous toadstool” grows (Lautréamont, 1965, chap. 4).

Meanwhile, the Japanese butoh dancer is demasculinized and dehumanized—although wearing the epitome of men's civilized clothes, the typical dark suit of Japanese or western businessmen - through the loss of his face, since he is wearing an embroidered mask. Embroidery is not only traditionally a women's task or job, but it is also associated to "feminine" qualities such as delicateness, patience, daintiness... In this scene, the lightcolored, pinkish lace mask sharply contrasts with the darkness of the dancer's costume and of the rest of the scenery. The only object onstage is a piano, also a musical instrument - or often, more accurately, a piece of furniture - traditionally linked to middle- and upper-class women; however, the dancer, instead of playing it, stamps his feet and hands on the keyboard while walking on all fours, obtaining dissonant sounds. The body attitude of the dancer, who mostly crouches and crawls, never adopting a stand-up position, and his body itself, which is that of an old, skinny, wrinkled, bald man, do not fit what is proper to masculinity: first, his pace is close to that of an animal, and secondly, his appearance is far from what is usually considered typically "masculine" (young, muscular, and hairy). (See Image no. 1) 


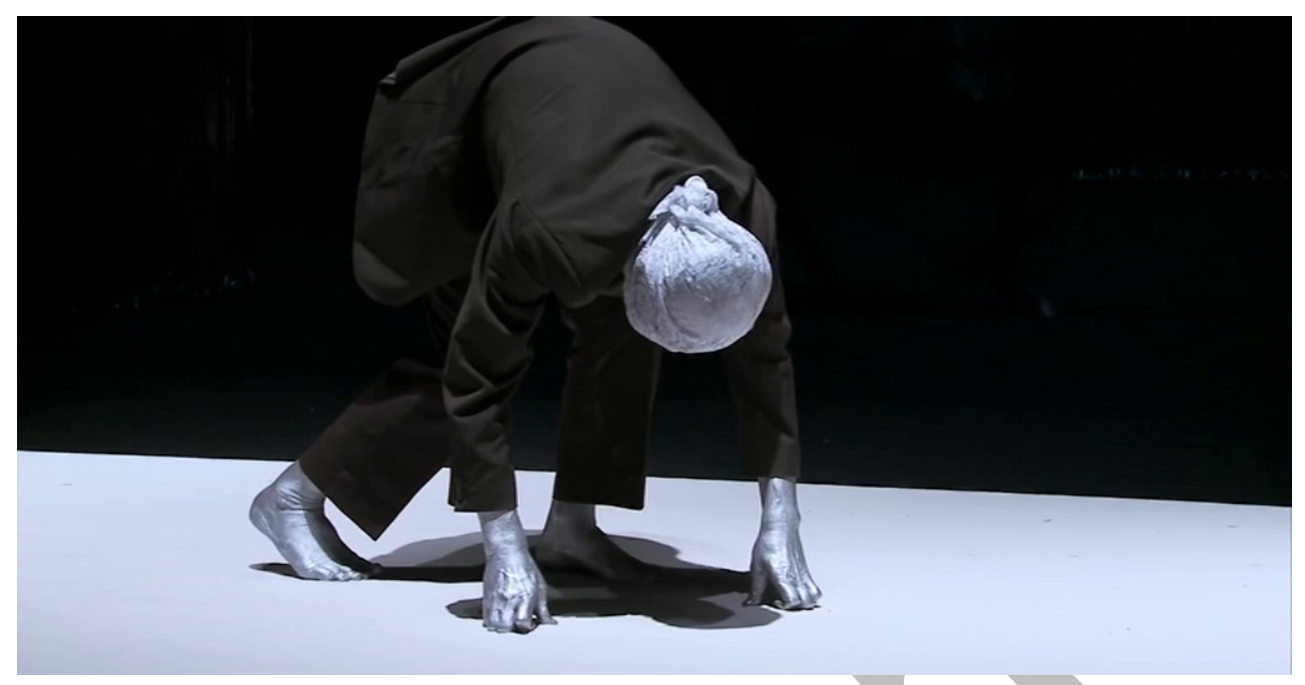

Image 1: Bartabas, The Centaur and the Animal

Lautréamont's recited verses insist on this demasculinization: not only do they allude to castration ("An evil viper has devoured my penis and taken its place. The villain has made a eunuch out of me. Ah! If only I had been able to defend myself with my paralyzed arms"; Lautréamont, 1965, chap. 4), but also to paralysis and helplessness, contrary to the "masculine" obligation to fight back. The dancer's movements and attitudes often suggest fear, submissiveness and weakness, which have been always related to femininity—and also to certain animals usually considered as preys, such as most herbivores.

In two posterior scenes, a horse actor appears on stage, the horse's body merging with the rider's body, also covered with a large veil. This sort of "centaur" (since it is a creature apparently formed by a human and a horse) does not appear as a virile, conquering figure, but rather adopts a "feminine" attitude (hunched, head bent, moving his/her/their hands as begging or praying...). In one of these scenes (29'-30') this hybrid creature seems to hunt, or haunt, an unsexed human dancer - since he or she, although apparently naked, wears a tight black outfit that paradoxically androgynizes the actor-, who seems to be afraid while avoiding being caught. However, the scene is ambiguous since both figures move in a 
symmetrical way, as in a mirror, each being the hunter and the prey, the original and the reflection... (See Image no. 2.)

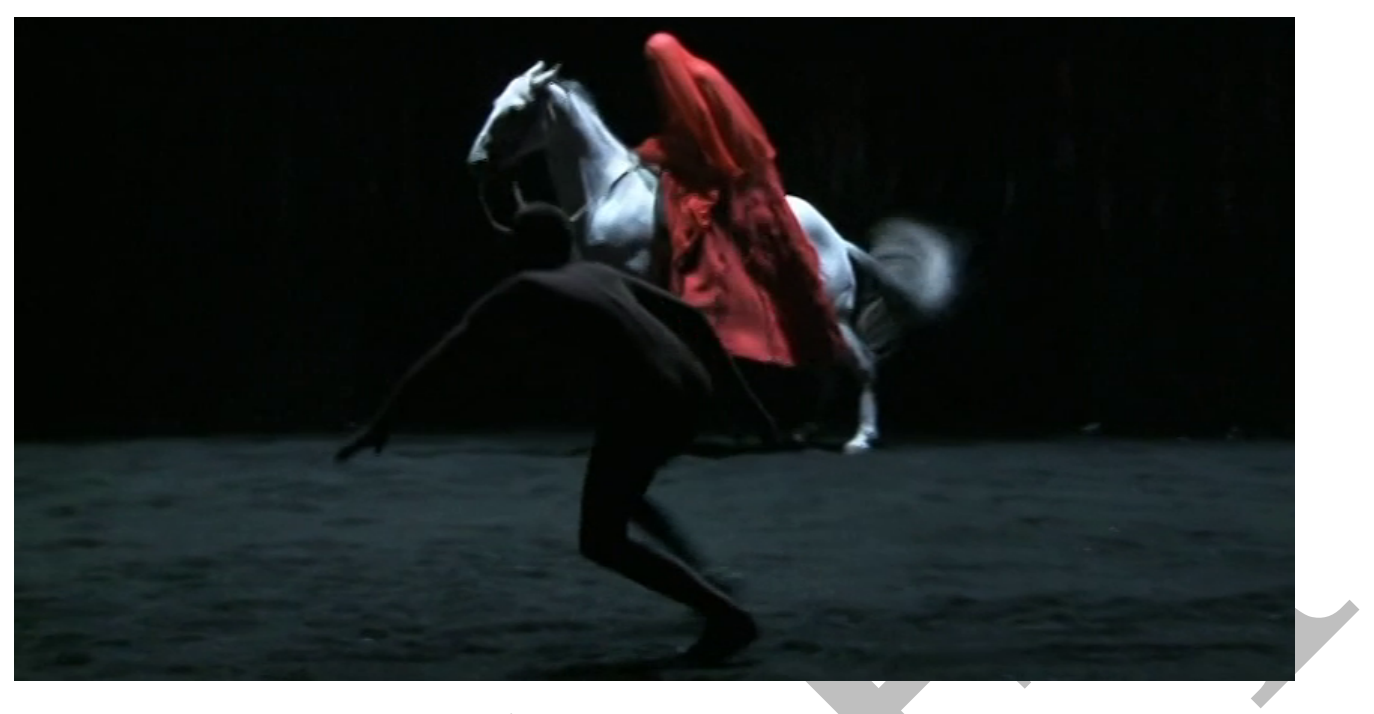

Image 2: Bartabas, The Centaur and the Animal

\section{The Loss of the Face}

The face is traditionally considered the most human part of the body, that which defines us as human beings, separated from animals, since it allows us to recognize each other as singular individuals. Moreover, as proven by the popular saying "the eyes are the mirror of the soul," the human face, and more precisely the gaze, reflects our supposedly exceptional transcendence. Nevertheless, nothing is less natural than a face: the etymology of the word 'face' in English, faccia in Italian, or also faz in Spanish, already refers to the fabricated character of the face. This term derives from the Latin facia, which is related to the verb facere, 'to make;' other possibilities, such as the Spanish semblante or the French figure both refer to "fiction" (see Segarra, 2014).

The face is already a mask, in this sense, but by wearing a real, sometimes opaque, mask, the dancers stress this artificiality. We can also read their apparent blindness in 
different, and even opposite senses: on the one hand, it reinforces their dehumanization, since it is said that the eyes, the gaze, are the seat of humanity but also, simply of life, and that is why we close the eyes of the dead, for we cannot bear the death of the gaze. On the other hand, blindness accentuates the access to the interior being that the eyes are supposed to provide, as in those portraits commented upon by Jacques Derrida in Memoirs of the Blind (1993). For the French philosopher, this blindness is a metaphor for another type of vision, directed above all toward the subject's interior, but also toward the world surrounding him or her.

We could thus say that the mask contributes to the "deterritorialization" of the human body that butoh in general intends to achieve, by defacing the face and, thus, escaping from "faciality" as an element of "reterritorialization" of the body, which, by itself, does not have a clear order determined by nature, a single readability (Deleuze \& Guattari, 2004), especially in terms of gender binarism.

The elision of the face and of the gaze could lead us, of course, to another path, that of Emmanuel Levinas's consideration of the face as the image of the other that obliges me to notice "him," as the basis for an ethical relationship with this other (Levinas, 1969). When asked, the philosopher specified that this conception of ethics is only fully valid for human intraspecies relationships. ${ }^{10}$ But, as Judith Butler (2004) has well analyzed, some human lives

\footnotetext{
${ }^{9}$ Levinas uses the masculine form.
}

${ }^{10}$ The question is more complex in Levinas and cannot be summarized, in fact, as the animal has no face. Asked if there is "something distinctive about the human face which, for example, sets it apart from that of an animal," Levinas answers: "One cannot entirely refuse the face of an animal. Yet the priority here is not found in the animal, but in the human face. We understand the animal, the face of an animal, in accordance with Dasein. The phenomenon of the face is not in its purest form in the dog. In the dog, in the animal, there are other phenomena. For example, the force of nature is pure vitality. It is more this which characterizes the dog. But it also has a face" (1988, p. 169). Here the philosopher introduces a hierarchy that, in my view, is problematic within ethics, and relates it to "im/pure." Later in the same interview, to the question: "According to your analysis, the commandment "Thou shalt not kill' is revealed by the human face; but is the commandment not also expressed in 
come under the same category as animals, especially in the context of war. The reference to the Second World War from the vantage point of Hiroshima's people is also reflected in the ashen appearance of the dancer's skin, especially apparent in the first scene. ${ }^{11}$ We could also use here a Derridean reading of the "cinders" as the epitome of "dissemination" and impermanence (Derrida, 2014, p. 39), themselves at the very heart of butoh.

\section{The Androgynous Centaur}

The hybridization of the human actor and the horse actor is achieved in a key scene $\left(34^{\prime}-37^{\prime}\right)$, in which the visual effect is stunning. From the shadows, a mythical, hybrid creature appears, a real centaur, who stares at us with an impervious, inscrutable gaze, as that of Derrida's cat (2008). This is not an oppositional gaze, though, perhaps a hospitable one. The hybrid creature, wearing a long, black skirt that covers her/his/their body below the waist, has human arms and hands, which perform delicate gestures - usually deemed feminine, or effeminate if done by men-, flutter like wings and, finally, cover the eyes of the centaur, in another reference to blindness. The powerful symbolic connotation of the black horse sharply contrasts with the torso's pallor. It is a man's bust; however, in contrast with the darkness and massive physical presence of the horse, it seems weak and feminine. (See image no. 3.)

the face of an animal? Can an animal be considered as the other that must be welcomed? Or is it necessary to possess the possibility of speech to be a 'face' in the ethical sense?", the philosopher answers: "The human face is completely different and only afterwards do we discover the face of an animal. I don't know if a snake has a face. I can't answer that question. A more specific analysis is needed" (pp. 171-172). Levinas introduces here another hierarchy, among animals (a dog seeming to be more human than a snake-without ignoring the Biblical symbolism of the latter, of course). I do not know what Levinas would say about the face of a horse, however.

${ }^{11}$ Although Pagès (2015) considers that the nuclear bomb reference in butoh was exaggerated by western critics, she admits that the Second World War had an inarguable effect on butoh's creators, who were children or young men during the conflict. 


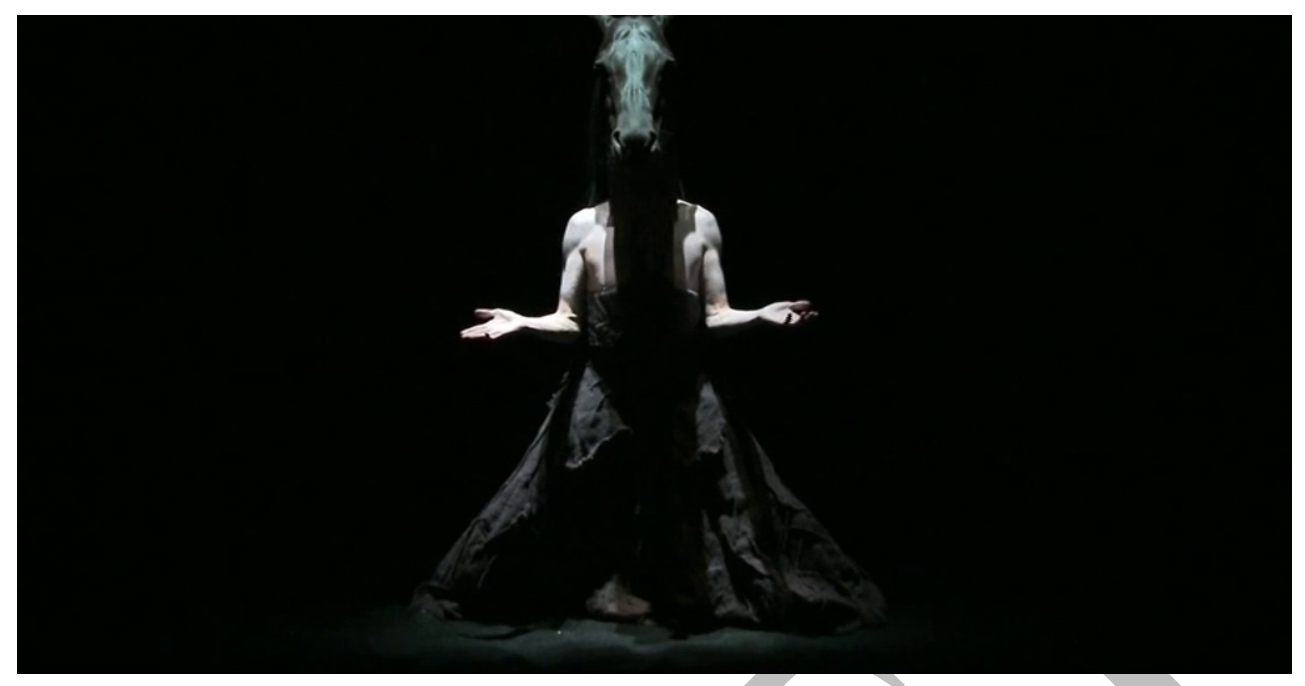

Image 3: Bartabas, The Centaur and the Animal

The Comte de Lautréamont's verses read during this brief but central scene allude to metamorphosis. The original text has been slightly but decisively modified: it is, in the play, in the first person instead of the third, and the word 'lamp' has been replaced by 'horse.' The scene written by Lautréamont is a confrontation between this animated object, a lamp in a temple, and the protagonist, Maldoror, who "tells himself that if there is any soul concealed within that lamp it is cowardly not to reply sincerely to a straightforward attack. He beats the air with his sinewy arms and wishes that the lamp could be transformed into a man; he promises himself that he would put him through a bad quarter-hour." But the narrator ironically concludes, "The means by which a lamp changes into a man are unnatural" (Lautréamont, 1965, chap. 2). The lamp ["horse" in the play] ${ }^{12}$ falls after Maldoror actually hits it, but resists his violence, growing bigger and developing "wings at its sides." This figure is then assimilated to an "angel": "He seems [I seem] to see wings sprouting from its sides and its upper part takes on the form of an angel's bust." The lamp/horse and the angel

\footnotetext{
12 The modified version in relation to the original is placed between square brackets in this quotation and the following ones.
} 
are "united in the same body." The narrator — as the spectators of the performance"recognizes [I recognize] the shape of the lamp [horse]; he recognizes [I recognize] the form of the angel; but he [I] cannot distinguish them in his [my] mind. Indeed, in reality they are joined together and form together one free and independent body" (Lautréamont, 1965, chap. 2). Bartabas amazingly reproduces onstage the vision of a real chimeric body, in which the masculine connotations of the horse are counterbalanced by the traditional androgyny of the angel. However, his visual translation of this episode from Les Chants de Maldoror is not confrontational nor violent; the human and the horse parts of the same body seem perfectly content to be united, and there is not a third part that would try to destroy the resultant centaur. The last sentences of Lautréamont's fragment included in the performance depict the fall of Maldoror "into the vertiginous abyss of evil," whereas "the angel ascends towards the serene heights of virtue" (Lautréamont, 1965, chap. 2). We will comment later on the fall, but in this scene, the centaur remains in a solid upright position.

This centaur inverts, however, the classical figure composed by a man's upper body and a horse's lower body. This reversal might point to a certain dehumanization of this creature, due to the loss of the human face. However, if the horselike face of the centaur may contradict, again, Levinas's disparaging comment on animals' face, its humanimal hands dispute Heidegger's statement that the animal has no hand; we may consider instead, in a "prosthetic logic" (Wills, 1995), that these human hands are part of the horse's body. Derrida had already deconstructed in "Geschlecht" (2007) the Heideggerian divide between humans and animals based on the hand arguing that Heidegger's thought on the hand is more related to the gift than to "handicraft." Here, according to Derrida's interpretation, the centaur would be gifted with the capacity of gift, usually thought as being a solely human trait.

Moreover, the direction of the gaze between human and nonhuman animals (which usually goes from the first to the second, as John Berger critically analyzed in his classic 
essay from 1980, “Why Look at Animals?”) is also reversed: it is the horse who looks at us with an enigmatic expression. Shortly after, the horse and the man appear again as two different beings, the first moving quietly on the stage and the latter crouched, hiding his bent head, only moving his hands and back, in a position that recalls a strange, birdlike animal. The horse observes the (not quite) human being, slowly approaches him, and strokes his hands and his back using his nose and tongue. This is also a reversal of the usual action of stroking with one's hand the neck of the horse one is riding; this scene is unsettling not only because of this inversion but also because the contact is sensually charged. We cannot conclude, thus, that in these scenes the animal is humanized nor that the human is animalized: they merge in a sort of third state — which would be that of the allegoric figure of Lautréamont's "angel"—-beyond binary oppositions such as animal/human but also feminine/masculine.

In a subsequent scene (44'-50'), the butoh dancer's body acquires a mineral quality, but also looks and moves around like an insect (see image no. 4). His back is strangely bent, and his extremities look like antennae, insect legs, and claws; he crawls, nearly falls aside, tries to stand up but falls seconds after having achieved a more or less vertical position. Throughout the whole performance, the dancer is almost never completely upright, and keeps falling, again and again. This fight for achieving verticality evokes a sort of evolutionary myth, which would be, however, rather than a success story, a nightmarish, twilight tale in the threshold between life and death, animate and inanimate, and also between different elements, such as water and earth. Besides, if "flesh" is the common substance shared by humans and animals, as well as other forms of life, following Cary Wolfe (2003, p. 52), this scene broadens the scope of biopolitics to a wider continuum including human, animal, vegetal, mineral and machine creatures. 


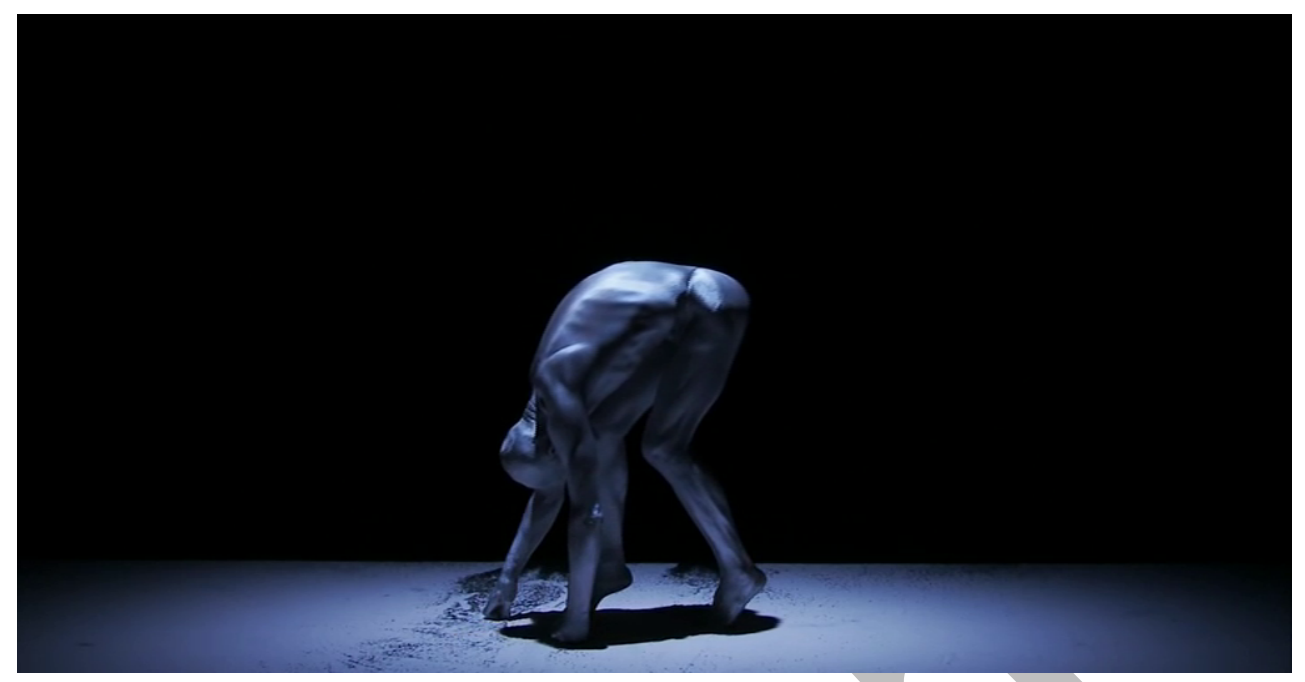

Image 4: Bartabas, The Centaur and the Animal

We will comment on a last scene (46'-50'), in which a white horse and his white rider (his skin being covered with white makeup) slowly fall together and lie completely motionless on the floor, as if dead, composing a still life. Meanwhile, the butoh dancer endures, without moving, a powerful stream of sand on his head. This rain of sand could be an allusion to temporality, through its similarity with an hourglass' mechanism. Sand timers are traditionally seen as icons of tempus fugit, that is, of the ineluctability of death and disappearance. But the fall of the horse and man takes place three times: the repetition of an event - death - that is supposed to happen only once in a lifetime also provokes a feeling of estrangement. After the third occurrence, there is a variation, though: the camera focuses on the horse's head, and the animal moves an ear, reminding us, somewhat ironically, that this is not an "inanimate" composition — the definition of still life pictures — but a living one, indeed. (See image no. 5.) 


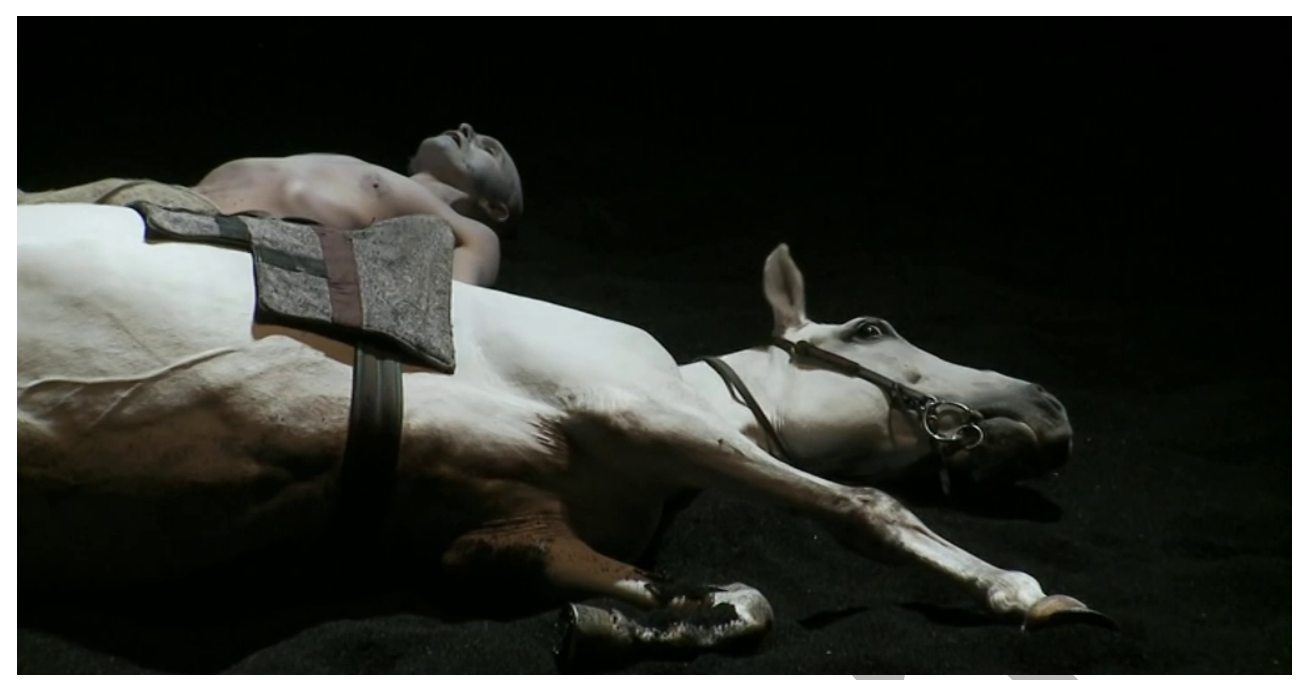

Image 5: Bartabas, The Centaur and the Animal

This ironic detail deconstructs in my view Lacan's belief that animals are not capable of "feigning feint" (see note 5), since the horse's ear movement seems to be the equivalent of a human wink, and introduces thus a second degree in the feigning or playing, a problematization of the scene's level of fiction. Of course, this interpretation comes from a human point of view-Bartabas's and the filmmaker's as well as the spectator's-, but the actual gesture comes from the horse, who becomes an accomplice of this ironic detail. Furthermore, because of the repetition of "death," the impression of seeing a dead body or an inanimate object is replaced by the image of extreme "passivity," the Derridean impouvoir, which can be defined as a radical "exposure" to the other and to the suffering of the other in which all "self-certainty" and "self-presence" are suspended (McCance, 2013, p. 68). This suspension provokes "a heightened sense of one's vulnerability" (p. 69) and impermanence, and a strong, blind connection with the other-animal, in a strong kinship bond. This extreme vulnerability and connection with the radical other are, again, contrary to hegemonic masculinity values, and usually considered to be "feminine." 


\section{The Debasement of Oppositions}

Bartabas's The Centaur and the Animal appears to be, in conclusion, a powerful claim for this close connection and kinship between humans and animals (or more accurately, horses), which goes as far as a dream of unity embodied in the centaur. This dream of reunion implies the debasement not only of the traditional opposition between humanity and animality — which is at the core of western philosophy—, but also of other oppositional pairs that form the binaries structuring our conception of the world and the beings and objects that inhabit it: reason vs. instinct, activity vs. passivity, verticality vs. horizontality (or "inclination," as Adriana Cavarero (2016) has theorized), immunity vs. vulnerability (Butler 2004, 2014), capacity vs. disability, animate vs. inanimate, ${ }^{13}$ and, of course, masculinity vs. femininity, which is, according to Cixous (1980) the pair that underlies all the others.

Nevertheless, this debasement of the two oppositions that are more central in my analysis (masculinity vs. femininity and humanity vs. animality) do not point to a feminization of the masculine or to an animalization of the human —or else to an anthropomorphizing of the animal. Indeed, Bartabas says in a filmed interview, Sur les pas du Centaure (Bartabas \& Gunst, 2012), that he intends to "de-animalize the horse," although he does not wish the horse to become a man but to "go towards the organic" (27'-28'). This intention-which coincides with butoh's general goal—seems to fit in what Deleuze and Guattari (2004) call a "becoming," through the deterritorialization of the human body, turning it into a "body without organs."

This "becoming" would go in the direction of the "posthuman," if this term is not understood as the end of actual humans as Haraway (2016) and many others seem to think: as it has been pointed out, the 'post' in 'posthuman' does not necessarily convey a sense of temporality

${ }^{13}$ See Mel Chen’s essay on “animacy” (2012). 
(what comes after the human) but indicates that 'human' is a historical category. The same would apply to 'animal,' hence the notion of "postanimal" coined by the editors of the Yale French Studies' issue on “animots" (Senior, Clark, \& Freccero, 2015). The horse actors-but also the human actors-in Le Centaure et l'Animal are "postanimals," in the sense that Senior, Clark and Freccero give to this term: "postanimals" amount to those beings freed from the constrictive dominant norms - including gender norms - that rule current intrahuman relationships and also relationships between human and nonhuman animals, giving way to other, liberating possibilities of ontological and living "choreographies" that would go beyond "inclusive masculinities," in favor of "post-masculinity." 14

\section{References}

Anderson, E. (2009). Inclusive masculinity. The changing nature of masculinities. New York, NY: Routledge.

Bartabas \& Gunst, J.L. (Directors) 2012. Sur les pas du centaure. France: La Compagnie des Indes.

Bartabas \& Vargioni, C. (Directors). 2012. Le centaure et l'animal. France: TF1 Video-Mk2.

Berger, A.E. (2011). When Sophie loved animals. In A.E. Berger \& M. Segarra (Eds.), Demenageries. Thinking (of) animals after Derrida (pp. 97-124). Amsterdam, The Netherlands: Rodopi.

Berger, J. (1980). Why look at animals? In J. Berger, About looking (pp. 1-26). New York, NY: Pantheon Books.

\footnotetext{
${ }^{14}$ As for the concept of "postmasculinity," see, for instance, Haywood and Mac an Gaill (2012). In a completely different mode, the term "post-masculinity" is also interestingly used by Jordanian artist Yazan Setabouha, which relates it to women's resistance against male domination: "Post-masculinity is a contemporary imaginary disease transmitted among the faces and bodies of women who are subject to inequality, enabling them to expose the realities they are living" (Post Masculinity, 2018).
} 
Berloni, W.M., (2017). Revisiting the history of the implementation of animal welfare policies in theater and film productions: An interview with William M. Berloni, leading animal trainer in Broadway shows. (I. Ramos Gay \& C. Alonso Recarte, Interviewers). Revista General de Derecho Animal y Estudios Interdisciplinares de Bienestar Animal / Journal of Animal Law \& Interdisciplinary Animal Welfare Studies, 0, 1-25.

Buber, M. (1965). Between man and man. New York, NY: Macmillan.

Butler, J. (2004). Precarious life: The powers of mourning and violence. London, UK: Verso. Butler, J. (2014). Bodily vulnerability, coalitions, and street politics. In J. Sabadell-Nieto \& M. Segarra (Eds.), Differences in common. Gender, vulnerability and community (pp. 99-119). New York, NY: Rodopi.

Cavarero, A. (2016). Inclinations. A critique of rectitude. Stanford, CA: Stanford University Press.

Chaudhuri, U. (2010). Entertainment and amusement. Animals in the performing arts. In M. Bekoff (Ed.), The encyclopedia of animal rights and animal welfare (2 $\left.{ }^{\text {nd }} \mathrm{ed}.\right)$, (Vol. 1, pp. 212-21). Santa Barbara, CA: Greenwood.

Chen, M. (2012). Animacies: Biopolitics, racial mattering, and queer affect. Durham, NC: Duke University Press.

Cixous, H. (1980). Sorties: Where is she. (A. Liddle, Trans.). In E. Marks \& I. de Courtivron, New French feminisms: An anthology (pp. 90-98). Amherst: University of Massachusetts Press.

Connell, R. W. (2005). Masculinities (2 ${ }^{\text {nd }}$ ed.). Cambridge, UK: Polity.

Dashper, K. (2012). Dressage is full of queens! Masculinity, sexuality, and equestrian sport. Sociology, 46(6), 1109-24.

Deleuze, G., \& Guattari, F. (2004). A thousand plateaus. Capitalism and schizophrenia. London, UK: Continuum. 
Derrida, J. (1982). Choreographies. (C. MacDonald, Interviewer). Diacritics, 12(2), 66-76.

Derrida, J. (1993). Memoirs of the blind. Chicago, IL: The University of Chicago Press.

Derrida, J. (2007). Geschlecht II: Heidegger's hand. In J. Sallis (Ed.), Deconstruction and philosophy. The texts of Jacques Derrida (pp. 161-96). Chicago, IL: The University of Chicago Press.

Derrida, J. (2008). The animal that therefore I am. (D. Willis, Trans.). New York, NY: Fordham University Press.

Derrida, J. (2009). The beast and the sovereign (Vol. 1). (G. Bennington, Trans.). Chicago, IL: The University of Chicago Press.

Derrida, J. (2014). Cinders. Minneapolis: University of Minnesota Press.

Donovan, J. 2016. The aesthetics of care. On the literary treatment of animals. New York, NY: Bloomsbury.

Dumézil, G. (1929). Le problème des centaures. Étude de mythologie comparée indoeuropéenne. Paris, France: Paul Geuther.

Evans, N. (1995). The horse whisperer. New York, NY: Delacorte.

Graves, R. (1955). The Greek myths. London, UK: Penguin.

Haywood, C., \& Mac an Gaill, M. (2012). “What's next for masculinity?” Reflexive directions for theory and research on masculinity and education. Gender and Education, 24(6), 577-92.

Haraway, D.J. (2003). The companion species manifesto. Dogs, people, and significant otherness. Chicago, IL: Prickly Paradigm Press.

Haraway, D.J. (2008). When species meet. Minneapolis: University of Minnesota Press.

Haraway, D.J. (2016). Staying with the trouble. Making kin in the Chthulucene. Durham, NC: Duke University Press.

Hearne, V. (1986). Adam's task. Calling animals by name. New York, NY: Alfred A. Knopf. 
Lacan, J. (2006). Écrits: The first complete edition in English. (R. Fisk, Trans.). New York, NY: Norton.

Lautréamont, Comte de [Isidore Ducasse]. 1965. Les chants de Maldoror [Kindle version].

(G. Wernham, Trans.). New York, NY: New Directions.

Levinas, E. (1969). Totality and infinity. An essay on exteriority. (A. Lingis, Trans.).

Pittsburgh, PA: Duquesne University Press.

Levinas, E. (1988). The paradox of morality: An interview with Emmanuel Levinas. (T.

Wright, P. Hughes \& A. Ainley, Interviewers). In R. Bernasconi \& D. Wood (Eds.), The provocation of Levinas: Rethinking the other (pp. 160-180). London, UK:

Routledge.

Marquié, H. (2009). À la recherche de l'animal qui danse, ou l'invention de nouveaux corps

dansants. In B. Sibona (Ed.), Notre animal intérieur et les théories de la créativité (pp. 121-138). Paris, France: L’Harmattan.

Marquié, H. (2014). Non, la dans n'est pas un truc de filles! Essai sur le genre et la danse.

Toulouse, France: Éditions de l'Attribut.

Marra, K. (2014). Horseback views. A queer hippological performance. In U. Chaudhuri \& H. Hughes (Eds.), Animal acts. Performing species today (pp. 111-130). Ann Arbor: University of Michigan Press.

McCance, D. (2013). Critical animal studies: An introduction. Albany, NY: SUNY Press.

Nanako, K. (2000). Hijikata Tatsumi: The words of butoh. TDR, 44(1), 10-28.

Ortiz Robles, M. (2016). Literature and animal studies. London, UK: Routledge. Pagès, S. (2015). Le butô en France. Pantin, France: Centre national de la danse.

Patton, P. (2003). Language, power, and the training of horses. In C. Wolfe (Ed.), Zoontologies. The question of the animal (pp. 83-99). Minneapolis: University of Minnesota Press. 
Post Masculinity. (2018, January 13). [post in webzine My Kali]. Retrieved from https://www.mykalimag.com/en/2018/01/13/post-masculinity/

Sanders, V. (1988). Dancing and the dark soul of Japan: An aesthetic analysis of butō. Asian Theatre Journal, 5(2), 148-163.

Segarra, M. (2014). Teoría de los cuerpos agujereados. Santa Cruz de Tenerife, Spain: Melusina.

Senior, M., Clark, D.J., \& Freccero, C. (2015). Editors' Preface. Ecce animot: Postanimality from cave to screen. In Senior, M., Clark, D.J., \& Freccero, C. (Eds.), Animots: Postanimality in French Thought. Yale French Studies, 127, 1-18.

Sibona, B. (2014). Homo porosus. L'homme poreux et ses animaux intérieurs. Dijon, France: Éditions Universitaires de Dijon.

Tait, P. (2012). Wild and dangerous performances: Animals, emotions, circus. Basingstoke, UK: Palgrave Macmillan.

Wills, D. (1995). Prosthesis. Bloomington, IN: Stanford University Press.

Wolfe, C. (2003). Animal rites: American culture, the discourse of species, and posthumanist theory. Chicago, IL: The University of Chicago Press. 